\title{
Evaluation of the effectiveness of ozone as a sanitizer for fish experimentally contaminated with Salmonella sp.
}

\author{
Avaliação da eficácia de ozônio como sanitizante para peixes contaminados \\ experimentalmente por Salmonella sp.
}

\author{
Danielle de Bem Luiz ${ }^{1 *}$, Carlos Danger Ferreira e Silva², Simone Rodrigues Campelo1, \\ Viviane Rodrigues Verdolin dos Santos ${ }^{1}$, Leandro Kanamaru Franco de Lima', \\ Patrícia Costa Mochiaro Soares Chicrala', Marina Keiko Pieroni Iwashita ${ }^{3}$

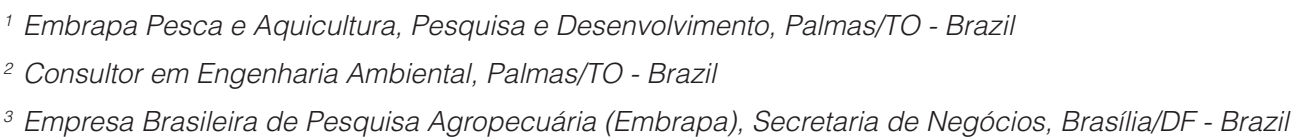

\section{*Corresponding Author}

Danielle de Bem Luiz, Embrapa Pesca e Aquicultura, Pesquisa e Desenvolvimento, Prolongamento da Avenida NS 10, cruzamento com a Avenida LO 18, sentido Norte, s/n, Loteamento Água Fria, CEP: 77008-900, Palmas/TO - Brasil, e-mail: danielle.luiz@embrapa.br

Cite as: Evaluation of the effectiveness of ozone as a sanitizer for fish experimentally contaminated with Salmonella sp. Braz. J. Food Technol., v. 20, e2016150, 2017

Received: Oct. 21, 2016; Accepted: Apr. 24, 2017

\section{Abstract}

Salmonellosis is a major public health problem related to food contamination and ensuing food poisoning. Brazilian resolution RDC n 12/2001 of the Brazilian National Health Surveillance Agency (ANVISA) established the absence of Salmonella in $25 \mathrm{~g}$ of fish for consumption. However, the significant increase in the occurrence of fish contamination by Salmonella and other pathogenic bacteria shows that the currently applied strategies are not sufficient and that, in addition to the implementation of good health practices, the application of new sanitizer technologies in the fish industry is also necessary. In this context, the present study evaluated the effectiveness of ozone in an aqueous medium as a sanitizer for Salmonella contaminated fish. The experiment was carried out using a completely randomized design with eight treatments and five replicates, giving a total of 40 experimental units. Each sample consisted of three fishes, totalizing 120 fishes. The treatments consisted of different combinations of temperature and water-dissolved ozone $\left(\mathrm{O}_{3}\right)$ concentrations $\left(21^{\circ} \mathrm{C} \times 0.35 \mathrm{ppm}\right.$; $20^{\circ} \mathrm{C} \times 0.45 \mathrm{ppm} ; 21^{\circ} \mathrm{C} \times 0.60 \mathrm{ppm} ; 20^{\circ} \mathrm{C} \times 0.80 \mathrm{ppm} ; 19^{\circ} \mathrm{C} \times 1.7 \mathrm{ppm} ; 6 \times 5.1 \mathrm{ppm} ; 4^{\circ} \mathrm{C} \times 7.2 \mathrm{ppm}$; and $\left.2{ }^{\circ} \mathrm{C} \times 9.1 \mathrm{ppm}\right)$. Colossoma macropomum (Tambaqui) samples were experimentally infected with Salmonella typhymurium (ATCC 14028) and immersed in water with the different treatments. After three minutes, the fish samples were collected and subjected to qualitative Salmonella analyses. The ozone tests were not efficient in eradicating Salmonella under the experimental conditions presented here, indicating the need for the identification of effective sanitizers in order to meet the determinations of Brazilian law.

Keywords: Microbiology; Tambaqui; Colossoma macropomum; Ozonation.

\section{Resumo}

A contaminação de alimentos com Salmonella e, consequentemente, a toxinfecção alimentar, é um importante problema de saúde pública. No Brasil, a Resolução da ANVISA RDC n 12/2001 para pescado preconiza que a Salmonella deve estar ausente em 25 gramas do produto a ser consumido. Porém, o aumento significativo na ocorrência de contaminação de pescado por Salmonella e por outras bactérias patogênicas demonstra que as estratégias atualmente utilizadas não têm sido suficientes e que, além da implementação de boas práticas sanitárias, é necessária, também, a aplicação de novas tecnologias sanitizantes na indústria de pescado. Neste contexto, o presente estudo avaliou a eficácia de ozônio em meio aquoso como agente sanitizante de pescado contaminado. O experimento foi desenvolvido em delineamento inteiramente casualizado com oito tratamentos, que consistiram em diferentes combinações de temperatura e concentração de ozônio 
Evaluation of the effectiveness of ozone as a sanitizer for fish experimentally contaminated with Salmonella sp.

Luiz, D. B. et al.

$\left(21^{\circ} \mathrm{C} \times 0,35 \mathrm{ppm} ; 20{ }^{\circ} \mathrm{C} \times 0,45 \mathrm{ppm} ; 21^{\circ} \mathrm{C} \times 0,60 \mathrm{ppm} ; 20{ }^{\circ} \mathrm{C} \times 0,80 \mathrm{ppm} ; 19{ }^{\circ} \mathrm{C} \times 1,7 \mathrm{ppm} ; 6{ }^{\circ} \mathrm{C} \times 5,1 \mathrm{ppm}\right.$; $4{ }^{\circ} \mathrm{C} \times 7,2 \mathrm{ppm} ; 2^{\circ} \mathrm{C} \times 9,1 \mathrm{ppm}$ ), com cinco repetições por tratamento, totalizando 40 amostras compostas (três peixes por amostra). Para tanto, 120 peixes da espécie Colossoma macropomum (Tambaqui) foram contaminados experimentalmente com Salmonella typhymurium (ATCC 14028) e, em seguida, imersos em recipientes contendo os tratamentos testados. Após um período de três minutos, as amostras de peixes foram coletadas e submetidas à análise qualitativa de Salmonella. Os testes realizados com ozônio não foram eficientes para erradicar Salmonella nas condições experimentais apresentadas, indicando a necessidade de identificação de agentes sanitizantes eficientes, a fim de atender à determinação da legislação brasileira.

Palavras-chave: Microbiologia; Tambaqui; Colossoma macropomum; Ozonização.

\section{Introduction}

The size of the contamination and the kind of microorganisms found in fish and fishery products depend on several aspects, such as location and method of capture or farming, season, handling, processing and storage, amongst others (GONÇALVES; OLIVEIRA, 2016). Foodborne diseases are usually caused by the ingestion of contaminated products. In addition, the microbiological quality of these products is also related to post-harvesting management, in other words, good handling and manufacturing practices are essential for food security in the transport, storage, handling and processing stages (JAKABI et al., 1999).

Amongst the main food contaminants, Salmonella is one of the main causes of foodborne illnesses in many parts of the world. The ubiquitous nature of this microorganism and the numerous serotypes present in various foodstuffs are a major challenge for researchers who strive for its elimination. Thus, in the last decade, many innovative technologies have emerged with great potential to inactivate Salmonella and other foodborne pathogens, particularly with regard to fresh fish (CARRASCO et al., 2012; MUKHOPADHYAY; RAMASWAMY, 2012; SCALLAN et al., 2015; SILVA, 2015; GONÇALVES; OLIVEIRA, 2016; BAKA et al., 2017).

Sodium hypochlorite is the most widely used compound in food sanitation. However, chlorine is not a friendly chemical, as it can react with organic material, forming organochlorines such as trihalomethanes, considered to be potential carcinogens (NASCIMENTO; SILVA, 2010; AL-OMARI et al., 2014). Thus studies are now being carried out to evaluate alternative sanitizers that show lesser impact on receiving water bodies, that do not form toxic byproducts and that can easily eliminate their excess concentrations (RAMOS et al., 2013; ACHILLEOS et al., 2005; EPA, 2004).

Amongst these emerging technologies, the use of ozone, which, due to its powerful oxidant effect, is characterized as one of the most powerful disinfectants, is noteworthy (LANITA; SILVA, 2008; GONÇALVES, 2016), causing cell inactivation by direct membrane and cell wall damage, disruption of enzymatic reactions and DNA damage (EPA, 2004; VON GUNTEN, 2003; GONÇALVES; OLIVEIRA, 2016). In addition, several studies have shown that its use presents low potential with regard to changes in the sensory characteristics of food, which expands the possibilities for its use (USEPA, 1999; WHANG et al., 2004; ALEXANDRE et al., 2011; MUKHOPADHYAY; RAMASWAMY, 2012).

It is not enough to just select a powerful sanitizing agent; the concentrations required and the efficiency of the disinfection process are of critical importance with respect to the prevention of pathogen survival, ensuring that it is safe to use the final product. In addition, maintaining an adequate level of sanitizer in the washing water can be a challenge to the industry, due to the high organic load of their washing systems (ZHOU et al., 2015).

This aspect becomes more relevant in the fish processing scenario in Brazil, since the RDC Resolution No. 12 of January 2, 2001, of the Agência Nacional de Vigilância Sanitária (ANVISA) of the Brazilian Ministry of Health (MS), states that Salmonella must be absent in $25 \mathrm{~g}$ of the product to be consumed (BRASIL, 2001). In addition, in Brazil, chlorine is currently the only sanitizer permitted by law by the national inspection agency (Ministério da Agricultura, Pecuária e Abastecimento, MAPA) for fish cleaning processes.

The efficiency of using ozone in reducing microbial counts depends on many factors, e.g. ozone concentration and time of exposure, type of produce, temperature, microbial populations and packaging material (GLOWACZ; REES, 2016; HORVITZ; CANTALEJO, 2014; GONÇALVES; OLIVEIRA, 2016).

Considering these factors and the lack of studies on the application of ozone as a sanitizer in the initial washing process of whole fish in fish warehouses, the present study aimed to evaluate the effect of using different combinations of temperature and water-dissolved ozone concentrations for the elimination of Salmonella during fish cleaning processes in fish warehouses, considering the microbiological standards set forth by Brazilian law.

\section{Material and methods}

\subsection{Fish samples}

Tambaqui (Colossoma macropomum) specimens, a species representative of commercial interest in northern Brazil, were purchased slaughtered after fasting for 24 hours, 
Evaluation of the effectiveness of ozone as a sanitizer for fish experimentally contaminated with Salmonella sp.

Luiz, D. B. et al.

originating from farms located in Palmas, TO, Brazil. The specimens had live weights of from $400 \mathrm{~g}$ to $750 \mathrm{~g}$.

\subsection{Salmonella strains}

Salmonella typhimurium strains (ATCC 14028) were used, acquired from the reference microorganism collection at the Oswaldo Cruz Foundation (FIOCRUZ, Brazil). Freeze-dried bacterial strains were re-suspended and homogenized in $0.5 \mathrm{~mL}$ Brain Heart Infusion Broth $(\mathrm{BHI})$, according to the culture rehydration instructions provided by FIOCRUZ. After resuspension, the strains were inoculated into the same broth and incubated in a bacteriological incubator at $37^{\circ} \mathrm{C}$ for 24 hours. The strains were then maintained in $\mathrm{BHI}$ broth, under refrigeration, and either sub-cultured periodically or inoculated into Selective Nutrient Broth for Salmonella (3M ${ }^{\mathrm{TM}}$, Brazil) and incubated for 24 hours at $41^{\circ} \mathrm{C}$ to carry out the experimental fish contamination.

\subsection{Contaminant suspension preparation}

The Salmonella typhimurium concentrations in the contaminant suspension were estimated by the turbidimetric method. After 24 hours in Selective Nutrient Broth for Salmonella $\left(3 \mathrm{M}^{\top \mathrm{M}}\right.$, Brazil), a $2 \mathrm{~mL}$ aliquot of the bacterial suspension was removed for spectrophotometric measurements using Salmonella-free Selective Nutrient Broth as the blank. The contaminant suspension was adjusted to an optical density range of 0.1 to $0.5\left(10^{4}\right.$ to $\left.10^{8} \mathrm{CFU} \mathrm{mL}{ }^{-1}\right)$ at $540 \mathrm{~nm}$ and kept refrigerated until analyzed (HANNA et al., 2011).

\subsection{Experimental fish contamination}

Fish contamination was carried out in a previously sanitized and disinfected container. Using a sterile spray, the contaminating Salmonella suspension was sprayed twice on each side of the fish, using about $0.5 \mathrm{~mL}$ of the bacterial suspension. After 5 to 10 minutes, the contaminated samples were homogenized for the ozone treatments.

\subsection{Treatments}

\subsubsection{Experimental design}

The experiment was carried out using a completely randomized design with eight treatments and five replicates, giving a total of 40 experimental units. Each sample consisted of three fishes, totalizing 120 fishes. The treatments consisted of different combinations of temperature and water-dissolved ozone $\left(\mathrm{O}_{3}\right)$ concentrations $\left(21^{\circ} \mathrm{C} \times 0.35 \mathrm{ppm}\right.$; $20^{\circ} \mathrm{C} \times 0.45 \mathrm{ppm} ; 21^{\circ} \mathrm{C} \times 0.60 \mathrm{ppm} ; 20^{\circ} \mathrm{C} \times 0.80 \mathrm{ppm}$; $19{ }^{\circ} \mathrm{C} \times 1.7 \mathrm{ppm} ; 6{ }^{\circ} \mathrm{C} \times 5.1 \mathrm{ppm} ; 4^{\circ} \mathrm{C} \times 7.2 \mathrm{ppm}$; and $\left.2{ }^{\circ} \mathrm{C} \times 9.1 \mathrm{ppm}\right)$. Each experimental unit was placed in a previously sterilized $20 \mathrm{~L}$ capacity plastic container, which was attached to a $500 \mathrm{~L}$-capacity tank.

\subsubsection{Ozone treatments}

The experimental units were supplied with the ozonated water solution in a continuous flow with an average flow of $7 \mathrm{~L} \mathrm{~min}{ }^{-1}$. Three fish previously infected with Salmonella typhymurium were immersed for three minutes in each experimental unit. The fish were subsequently removed with sterile tongs and sent for qualitative analysis regarding Salmonella. The three fish formed a composite sample. Thus, for each treatment, five samples were analyzed, giving a total of 15 fish. The three-minute period was previously determined to be the maximum time for the first fish washing procedure before starting sample processing (in cylinders or on washing mats) in fish processing industries.

In addition to the five repetitions, parallel tests were also carried out to verify if the fish were free from prior Salmonella infection and if contamination by spraying was effective. These tests were termed "positive and negative controls." Thus, three fish from each batch used in the treatments were analyzed for the presence of Salmonella (negative control), while three others were contaminated by spraying, according to the methodology employed herein, and analyzed for the presence of Salmonella (positive control).

\subsubsection{Water ozonation}

For the experimental tests designed to resemble the initial industrial washing of whole fish, a high capacity ozonation piece of equipment was used. The assembled system allowed for simultaneous repetitions and ozonation, water flow and system temperature control. These features contributed to the configuration of the system as a "pilot-scale", which facilitates the projection of the treatment on an industrial scale.

An ozonizer (Philozon, $\mathrm{O}_{3} \mathrm{R}$ ) with an oxygen concentrator at $92 \%\left(10 \mathrm{~L} \mathrm{~min}^{-1}\right)$, maximum ozone generation of $15 \mathrm{~g}$ of $\mathrm{O}_{3}$ at $8 \mathrm{~min}^{-1} \mathrm{~L}$ of $\mathrm{O}_{2}$ with a static mixer injection system/diffuser, bypass and one-inch venturi injector, was used. This equipment stored the ozonized water in a $500 \mathrm{~L}$ tank with a predetermined constant concentration displayed on the digital oxi-reduction (redox) potential (ORP) controller.

In addition to confirmation by the redox potential, the quantification of the dissolved ozone was also carried out using spectrophotometry (HACH DR 5000 spectrophotometer) with a $1.0 \mathrm{~cm}$ optical path quartz cell, considering a molar extinction coefficient of $\varepsilon=2950 \mathrm{M}^{-1} \mathrm{~cm}^{-1}$ at $258 \mathrm{~nm}$ (APHA, 2012).

\subsubsection{Sample analyses}

The three fish in each experimental unit were placed in sterile bags with $125 \mathrm{~mL}$ of peptone water, which was gently agitated for three minutes. A $25 \mathrm{~mL}$ aliquot of the peptone water was then removed and diluted with $225 \mathrm{~mL}$ 
Evaluation of the effectiveness of ozone as a sanitizer for fish experimentally contaminated with Salmonella sp.

Luiz, D. B. et al.

of enrichment medium (3M $\mathrm{M}^{\mathrm{TM}}$ ) and placed in an incubator for 24 hours at $41 \pm 0.5^{\circ} \mathrm{C}$. For the qualitative Salmonella analysis (presence/absence), a rapid Salmonella detection system was used, according to the manufacturer's instructions (Plate Petrifilm ${ }^{\mathrm{TM}}$ Salmonella Express System, 3M ${ }^{\mathrm{TM}}$ ).

The same procedure was carried out for each fish used in the positive and negative controls, with the difference that, in this case, each fish represented an experimental sample.

\section{Results and discussion}

The present study evaluated the efficacy of eight temperature and water-dissolved ozone concentration combinations as potential sanitizers for fish experimentally contaminated with $S$. typhimurium. When the treatments had dissolved ozone concentrations below or equal to 1.7 ppm (0.35 ppm, 0.45 ppm, 0.6 ppm, 0.8 ppm and $1.7 \mathrm{ppm}$ ) they were carried out at room temperature $\left(19^{\circ} \mathrm{C}\right.$ to $\left.21^{\circ} \mathrm{C}\right)$. These concentrations were unable to eliminate the presence of Salmonella after three minutes of treatment (Table 1)

To test the effect of higher dissolved ozone concentrations the water used to dissolve the ozone had to be cooled, so as to expand the saturation capacity of the solution (USEPA, 1999). Thus the effectiveness of the treatments with $5.1 \mathrm{ppm}, 7.2 \mathrm{ppm}$ and $9.1 \mathrm{ppm}$ were tested at temperatures of $6{ }^{\circ} \mathrm{C}, 4^{\circ} \mathrm{C}$ and $2^{\circ} \mathrm{C}$ respectively. All treatments showed the presence of Salmonella after 3 minutes of fish immersion (Table 1).

Different studies have reported the application of ozone in food sanitization, using different microorganisms as indicators. Koidiset al. (2000) evaluated the sanitizing effect of two aqueous ozone concentrations (1.4 ppm at $22{ }^{\circ} \mathrm{C}$ and $3.0 \mathrm{ppm}$ at $4{ }^{\circ} \mathrm{C}$ ) in shelled eggs inoculated with Salmonella enteritidis ( $7 \mathrm{log}$ ). The contaminated eggs were immersed for 30, 60 and 90 seconds in ozone solutions at the aforementioned concentrations.
Decreases of 1.02, 1.19 and 1.37 log units, respectively, were observed at $1.4 \mathrm{ppm}$ and at $3.0 \mathrm{ppm}$, decreases of 2.12, 2.34 and $2.47 \mathrm{log}$ units, respectively, were observed. However, the microorganism evaluated was not eliminated from any of the samples.

In another study, Ölmez and Akbas (2009) evaluated the use of aqueous ozone as a sanitizer for lettuce leaves contaminated with Listeria monocytogenes (8 log). The authors immersed lettuce leaves in contaminated solutions with concentrations ranging from 0.5 to $4.5 \mathrm{ppm}$ with exposure times from 0.5 to 3.5 minutes. Under these conditions, they found decreases ranging between 1.5 and $2.4 \log$ Listeria CFU. It is noteworthy that the maximum decreases were observed above 3 ppm, with higher concentrations showing no significant changes in the microbial counts. Furthermore, the highest microbial decreases were observed between two and three minutes of exposure, with no further significant decreases identified after two minutes.

Alexandre et al. (2013) tested the sanitizing effect of sodium hypochlorite, hydrogen peroxide, water-dissolved ozone, UV radiation and ultrasound to assess their applicability as pretreatments for freezing peppers contaminated with Listeria $(7.27 \mathrm{log})$. Regarding ozone, the peppers were dipped into a 0.3 ppm solution for two minutes, and a decrease of $2.25 \mathrm{log}$ Listeria CFU was noted. For this experiment the authors concluded that, despite hydrogen peroxide (1\% and $5 \%$ ) showing greater decreases in Listeria CFU (2.54 and $3.68 \mathrm{log}$, respectively), its application resulted in negative impacts regarding pepper color and firmness, impacts which were not observed with the use of ozone. Thus, of the treatments evaluated, ozone was elected the most suitable prior to pepper freezing.

Singh et al. (2003) tested different concentrations of ozonated water (4.60 ppm, 9.27 ppm and $14.3 \mathrm{ppm}$ ) and different immersion times (3, 5 and 10 minutes) to eliminate the presence of Escherichia coli O157:H7 in

Table 1. Analysis of the presence of Salmonella after the application of different ozone concentrations to experimentally contaminated tambaqui (Colossoma macropomum) samples.

\begin{tabular}{|c|c|c|}
\hline $\begin{array}{c}\mathrm{O}_{3} \text { concentrations } \\
(\mathrm{ppm})\end{array}$ & $\begin{array}{c}\text { Temperature } \\
\left({ }^{\circ} \mathrm{C}\right)\end{array}$ & $\begin{array}{l}\text { Salmonella analyses } \\
\text { (Number of replicates/Number } \\
\text { of replicates with presence of } \\
\text { Salmonella) }{ }^{1}\end{array}$ \\
\hline 0.35 & 21 & $5 / 5$ \\
\hline 0.45 & 20 & $5 / 5$ \\
\hline 0.6 & 21 & $5 / 5$ \\
\hline 0.8 & 20 & $5 / 5$ \\
\hline 1.7 & 19 & $5 / 5$ \\
\hline 5.1 & 6 & $5 / 5$ \\
\hline 7.2 & 4 & $5 / 5$ \\
\hline 9.1 & 2 & $5 / 5$ \\
\hline
\end{tabular}

${ }^{1}=05$ replicates were carried out for each treatment. 
alfalfa seeds. The presence of the bacterium was still observed in the seeds after all the treatments. Recently, Karaca and Velioglu (2014) tested the use of ozonated water (12 ppm) on the inactivation of Escherichia coli and Listeria innocua inoculated onto spinach, lettuce and parsley by dipping. The authors observed a reduction of $2.0 \pm 0.3 \mathrm{log}$ for $E$. coli and $2.2 \pm 0.1 \mathrm{log}$ for L. innocua and the use of ozone in an aqueous medium caused no changes in the characteristics of the vegetables analyzed.

Sengun (2014) tested the efficacy of ozonated water in reducing the counts of Salmonella Typhimurium. The treatment of carrots with ozonated water $(0.5 \mathrm{ppm}$, $1.0 \mathrm{ppm}$ and $1.5 \mathrm{ppm}$ ) for $3 \mathrm{~min}, 5 \mathrm{~min}$ and $10 \mathrm{~min}$ caused reductions in the number of Salmonella Typhimurium ranging between 0.37 and 2.72 log units, depending on the ozone concentration and exposure time used. However none of the treatments resulted in the complete inactivation of Salmonella.

Al-haddad et al. (2005) evaluated the effectiveness of Salmonella inactivation on chicken skin using ozone in a gaseous medium. According to this study, the authors inoculated $0.1 \mathrm{~mL}$ of a saline Salmonella infantis suspension $\left(1.5 \times 10^{4} \mathrm{CFU} \mathrm{mL} \mathrm{m}^{-1}\right)$ onto $10 \mathrm{~cm}^{2}$ of chicken skin, resulting

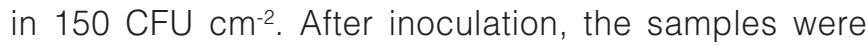
exposed to different treatments: (a) exposure to gaseous ozone near 3.000 (> 2.000) ppm for from 0 to 30 minutes; and (b) exposure to gaseous ozone concentrations near 3.000 (> 2.000) ppm for 15 minutes, followed by storage at $7{ }^{\circ} \mathrm{C}$ using a controlled atmosphere $\left(70 \% \mathrm{CO}_{2}: 30 \% \mathrm{~N}_{2}\right)$ for nine days. None of the treatments resulted in complete Salmonella inactivation, with maximum values of $97 \%$, the best condition for treatment being $\mathrm{O}_{3}$ gas for 15 minutes followed by nine days of storage in a controlled gaseous environment. The authors indicated that, although a bactericidal effect was observed, the Salmonella was not completely eradicated from the natural chicken substrate. Moreover, the authors attributed this result to the fact that the organic matter naturally present in the chicken skin absorbs and reduces the active ozone concentration. Consequently, the living Salmonella cells tend to be incorporated into the folds and skin pores, protecting the microorganisms from contact with the ozone molecules.

In a review on the use of emerging technologies in the control of Salmonella in foods, Mukhopadhyay and Ramaswamy (2012) indicated that the effectiveness of ozone treatments in both gaseous and liquid media was limited, when applied to substrates that show the presence of organic matter, such as foods (meat and vegetables) and environmental substrates (effluent and air). Furthermore, the type of organic matter may also interfere with the inactivation rate of the bacterium. The authors also observed that "it is not the total ozone applied, but indeed the residual ozone that has the best effect on Salmonella cells." Thus, long periods of storage may be required after applying ozone, whereas temperature is the main factor regarding the stability of residual ozone and the inactivation effect on the microorganisms. The authors noted that ozone treatments tend to be long in order to increase the efficiency of Salmonella inactivation. However, treatment times exceeding 10 minutes are not feasible for industrial food processing. Therefore, to reduce the treatment time and increase the inactivation rates of Salmonella, combinations of treatments such as UV $+\mathrm{O}_{3}$, increased temperature $+\mathrm{O}_{3}$, amongst others, are indicated (MUKHOPADHYAY; RAMASWAMY, 2012; XUE et al., 2016).

The complete elimination of the microorganisms analyzed was not observed in any of these studies, corroborating the data presented in the present study. However, Resolution ANVISA RDC No. 12/2001 for fish states that Salmonella must be absent in 25 grams of the product to be consumed. Thus considering this norm and the fact that the initial Salmonella contamination in the tambaqui samples was of $10^{4}$ to $10^{8} \mathrm{CFU}$, the ozone treatment was not effective in the eradication of Salmonella under the experimental conditions evaluated.

Regarding the inadequacy of ozone in eliminating Salmonella from the tambaqui samples under the conditions evaluated, some assumptions can be postulated, which corroborate those raised by Al-haddad et al. (2005) and cited previously:

1) The fish evaluated in the present study have scales and release a characteristic mucus, both of which probably act as physical barriers, hindering the action of the sanitizers in removing the microorganisms;

2) Scales, pores and the operculum located over the gills constitute a physical barrier to diffusion of the water containing the disinfecting agent, and make it difficult to complete the disinfection process;

3) The characteristic mucus and other impurities naturally present on fish surfaces are organic substances which react with the ozone molecules, i.e. are organic compounds that act as ozone molecule sequestering agents (ozone oxidizes organic matter), decreasing the availability (concentration) of this oxidant in the medium and consequently reducing the efficient inactivation of Salmonella on the surface of the fish.

\section{Conclusions}

Although studies that show the efficiency of ozone as a bactericide are available, reports of the complete inactivation of Salmonella in foods were not found. The present study demonstrated the inefficiency of ozone in the eradication of Salmonella under experimental conditions. These results suggest that (i) Salmonella can impregnate the pores present in the fish scales, hindering the effects of the ozone; (ii) the presence of a high organic load on the surface of the fish or diluted in the aqueous medium 
Evaluation of the effectiveness of ozone as a sanitizer for fish experimentally contaminated with Salmonella sp.

Luiz, D. B. et al.

decreases the ozone concentration and the efficiency of Salmonella inactivation.

However, although studies indicate the possibility of greater treatment efficiency by exposing the food to low ozone concentrations for longer periods of time, the search for emerging and safe bactericidal agents should consider the feasibility, both technical and economic, of the efficient eradication of Salmonella, also evaluating the sensory aspects and food safety.

\section{Acknowledgements}

The authors would like to acknowledge the National Council for Scientific and Technological Development (CNPq, process number 407728/2012-0), and the Ministry of Fisheries and Aquaculture and Water Resources Sector Fund of the Ministry of Science and Technology (CT-Hidro/ MCT) of Brazil, for the grants supporting this study.

\section{References}

ACHILLEOS, A.; KYTHREOTOU, N.; FATTA, D. Development of tools e guidelines for the promotion of sustenaible urgan wastewater treatment e reuse in the agricultural production in the Mediterranean countries: task 5 - technical guidelines on wastewater utilisation. Brussels: European Commission, Euro Mediterranean Partnership, 2005.

ALEXANDRE, E. M.; SANTOS-PEDRO, D. M.; BRANDÃO, T. R.; SILVA, C. L. Influence of aqueous ozone, blanching and combined treatments on microbial load of red bell peppers, strawberries and watercress. Journal of Food Engineering, London, v. 105, n. 2, p. 277-282, 2011. http://dx.doi.org/10.1016/j. jfoodeng.2011.02.032.

ALEXANDRE, E. M. C.; BRANDÃO, T. R. S.; SILVA, C. L. M. Impact of non-thermal technologies and sanitizer solutions on microbial load reduction and quality factor retention of frozen red bell peppers. Innovative Food Science \& Emerging Technologies, Amsterdam, v. 17, p. 99-105, 2013. http://dx.doi.org/10.1016/j. ifset.2012.11.009

AL-HADDAD, K. S. H.; AL-QASSEMI, R. A. S.; ROBINSON, R. K. The use of gaseous ozone and gas packaging to control populations of Salmonella infantis and Pseudomonas aeruginosa on the skin of chicken portions. Food Control, Guildford, v. 16, n. 5, p. 405-410, 2005. http://dx.doi.org/10.1016/j.foodcont.2004.04.009.

AL-OMARI, A.; MUHAMMETOGLU, A.; KARADIREK, E.; JIRIES, A.; BATARSEH, M.; TOPKAYA, B.; SOYUPAK, F. A review on formation and decay kinetics of trihalomethanes in water of different qualities. Clean - Soil, Air Water, Basel, v. 42, n. 12, p. 1687-1700, 2014. http://dx.doi.org/10.1002/clen.201300347.

AMERICAN PUBLIC HEALTH ASSOCIATION - APHA. Standard methods for the examination of water and wastewater. 22th ed. Washington, 2012.
BAKA, M.; VERHEYEN, D.; CORNETTE, N.; VERCRUYSSEN, S.; VAN IMPE, J. F. Salmonella Typhimurium and Staphylococcus aureus dynamics in/on variable (micro)structures of fish-based model systems at suboptimal temperatures. International Journal of Food Microbiology, Amsterdam, v. 240, p. 32-39, 2017. PMid:27627842. http://dx.doi.org/10.1016/j.ijfoodmicro.2016.08.004.

BRASIL. Agência Nacional de Vigilância Sanitária. Resolução $n^{\circ} 12$, de 2 de janeiro de 2001. Aprova o regulamento técnico sobre padrões microbiológicos para alimentos. Diário Oficial [da] República Federativa do Brasil, Brasília, DF, 10 jan. 2001.

CARRASCO, E.; MORALES-RUEDA, A.; GARCÍA-GIMENO, R. M. Cross-contamination and recontamination by Salmonella in foods: a review. Food Research International, Oxford, v. 45, n. 2, p. 545-556, 2012. http://dx.doi.org/10.1016/j.foodres.2011.11.004. ENVIRONMENTAL PROTECTION AGENCY - EPA. Guidelines for water reuse. Washington, 2004.

GLOWACZ, M.; REES, D. The practicality of using ozone with fruit and vegetables. Journal of the Science of Food and Agriculture, London, v. 96, n. 14, p. 4637-4643, 2016. PMid:27097728. http:// dx.doi.org/10.1002/jsfa.7763.

GONÇALVES, A. A. Ozone as a safe and environmentally friendly tool for the seafood industry. Journal of Aquatic Food Product Technology, United States, v. 25, n. 2, p. 220-229, 2016. http:// dx.doi.org/10.1080/10498850.2013.841785.

GONÇALVES, A. A.; OLIVEIRA, A. R. M. Elimination and control of pathogens by novel and hurdle technologies. In: GENÇ, I. Y.; ESTEVES, E.; DILER, A. (Ed.). Handbook of seafood: quality and safety maintenance and applications. New York: Nova Science Publishers, 2016. cap. 10, p. 175-190.

HANNA, J. F.; CASON, J. A.; RICHARDSON, J. R.; COX, N. A.; HINTON JUNIOR, A.; BUHR, R. J.; SMITH, D. P. Effect of stomaching on numbers of bacteria recovered from chicken skin. Poultry Science, Champaign, v. 90, n. 2, p. 491-493, 2011. PMid:21248349. http://dx.doi.org/10.3382/ps.2009-00477.

HORVITZ, S.; CANTALEJO, M. J. Application of ozone at the postharvest treatments of fruits and vegetables. Critical Reviews in Food Science and Nutrition, Boca Raton, v. 54, n. 3, p. 312-339, 2014. PMid:24188305. http://dx.doi.org/10.1080/104 08398.2011 .584353$.

JAKABI, M.; BUZZO, A. A.; RISTORI, C. A. Surtos alimentares de Salmonella spp. ocorridos na Grande São Paulo, no período de 1994 a 1997. Revista do Instituto Adolfo Lutz, São Paulo, v. 58, p. $47-51,1999$.

KARACA, H.; VELIOGLU, Y. S. Effects of ozone treatments on microbial quality and some chemical properties of lettuce, spinach, and parsley. Postharvest Biology and Technology, Amsterdam, v. 88, p. 46-53, 2014. http://dx.doi.org/10.1016/j. postharvbio.2013.09.003. 
Evaluation of the effectiveness of ozone as a sanitizer for fish experimentally contaminated with Salmonella sp.

Luiz, D. B. et al.

KOIDIS, P.; BORI, M.; VARELTZIS, K. Efficacy of ozone treatment to eliminate Salmonella enteritidis from eggshell surface. Archiv für Lebensmittelhygiene, Hanover, v. 51, n. 1, p. 4-6, 2000.

LANITA, C. S.; SILVA, S. B. Uso de ozônio em câmara industrial para controle de bolores e leveduras durante a maturação de queijo tipo parmesão. Brazilian Journal of Food Technology, Campinas, v. 11, n. 3, p. 182-189, 2008.

MUKHOPADHYAY, S.; RAMASWAMY, R. Application of emerging technologies to control Salmonella in foods: a review. Food Research International, Oxford, v. 45, n. 2, p. 666-677, 2012. http://dx.doi.org/10.1016/j.foodres.2011.05.016.

NASCIMENTO, M. S.; SILVA, N. Tratamentos químicos na sanitização de morango (Fragaria vesca L). Brazilian Journal of Food Technology, Campinas, v. 13, n. 1, p. 11-17, 2010. http://dx.doi.org/10.4260/BJFT2010130100002.

ÖLMEZ, H.; AKBAS, M. Y. Optimization of ozone treatment of fresh-cut green leaf lettuce. Journal of Food Engineering, London, v. 90, n. 4, p. 487-494, 2009. http://dx.doi.org/10.1016/j. jfoodeng.2008.07.026.

RAMOS, B.; MILLER, F. A.; BRANDÃO, T. R. S.; TEIXEIRA, P.; SILVA, C. L. M. Fresh fruits and vegetable: an overview on applied methodologies to improve its quality and safety. Innovative Food Science \& Emerging Technologies, Amsterdam, v. 20, p. 1-15, 2013. http://dx.doi.org/10.1016/j.ifset.2013.07.002.

SCALLAN, E.; HOEKSTRA, R. M.; ANGULO, F. J.; TAUXE, R. V.; WIDDOWSON, M.-A.; ROY, S. L.; JONES, J. L.; GRIFFIN, P. M. Foodborne illness acquired in the United States: major pathogens. Emerging Infectious Diseases, Atlanta, v. 17, n. 1, p. 7-15, 2015. PMid:21192848. http://dx.doi.org/10.3201/eid1701.P11101.

SENGUN, I. Y. Influence of ozonated water on microbial load and and shelf life of shredded carrots. Italian Journal of Food Science, Pinerolo, v. 26, p. 383-389, 2014.
SILVA, A. M. M. Efeito antimicrobiano do ozônio no processamento da tilápia do Nilo, Oreochromis niloticus (Linnaeus, 1758). 2015. 73 f. Dissertação (Mestrado em Produção Animal)-Programa de pós-graduação em Produção Animal, Universidade Federal Rural do Semi-árido, Mossoró, 2015.

SINGH, N.; SINGH, R.; BHUNIA, A. Sequential disinfection of Escherichia coli 0157:H7 inoculated alfalfa seeds before and during sprouting using aqueous chlorine dioxide, ozonated water, and thyme essential oil. LWT-Food Science and Technology, Campinas, v. 36, n. 2, p. 235-243, 2003.

UNITED STATES ENVIRONMENTAL PROTECTION AGENCY - USEPA. Alternative disinfectants and oxidants guidance manual. Washington, 1999.

VON GUNTEN, U. Ozonation of drinkingwater: Part II. disinfection e by-product formation in presence of bromide, iodide or chlorine. Water Research, Oxford, v. 37, n. 7, p. 1469-1487, 2003. PMid:12600375. http://dx.doi.org/10.1016/S0043-1354(02)00458-X.

WHANG, H.; FENG, H.; LUO, Y. Microbial reduction and storage quality of fresh-cut cilantro washed with acidic electrolyzed water and aqueous ozone. Food Research International, Oxford, v. 37, n. 10, p. 949-956, 2004. http://dx.doi.org/10.1016/j. foodres.2004.06.004

XUE, Z.; LI, J.; YU, W.; LU, X.; KOU, X. Effects of nonthermal preservation technologies on antioxidant activity of fruits and vegetables: a review. Food Science and Technology International, London, v. 22, n. 5, p. 440-458, 2016. PMid:26437672. http:// dx.doi.org/10.1177/1082013215606835.

ZHOU, B.; LUO, Y.; NOU, X.; LYU, S.; WANG, Q. Inactivation dynamics of Salmonella enterica, Listeria monocytogenes, and Escherichia coli 0157: H7 in wash water during simulated chlorine depletion and replenishment processes. Food Microbiology, Summit-Argo, v. 50, p. 88-96, 2015. PMid:25998820. http://dx.doi. org/10.1016/j.fm.2015.03.004. 